\title{
The Annual History of a Periodic Pond.
}

By

James Murray F. R. S.E.

The objects of this little investigation were to ascertain:

1. The life cycle of the various inhabitants of a periodic pond (i. e. one which only exists in winter, drying in summer).

2. The relation (if any) of the appearance of the different species to temperature and other conditions.

3. Whether the constituents of the population were constant from year to year.

4. Whether the life-cycle of the same species is the same in a periodic pond and in a permanent one.

The last was the principal object, and the one which induced me to begin the work. To attain it it was necessary to find 2 ponds, one temporary, the other permanent, in which some of the same species lived. Such ponds were accessible when I began, but I had to leave the locality of the permanent pond, and so only one-half of my object has been attained. As complete records of annual changes in single ponds are not too common it may be useful to publish this account. Anyone having access to a permanent pond where some of the same species live can readily complete the investigation.

The pond studied occupies a disused quarry (Nerston Quarry) from which basaltic rock has been taken for road-metal. It is situated near Glasgow, in about $55^{\circ} 50^{\prime}$ North latitude, and about 500 . feet above sea-level. When full it has a maximum depth of 6 feet, and measures about 30 yards by 20 yards. Its superficial area is then 4000 square feet, and the volume of water 12000 cubic feet.

On the south and west it is bounded by the rock-face of the quarry, a cliff about 10 feet high, opposite which stretches an open 
field. It is fed solely by rain, and the drainage of rain from a small part of the field. There is no outflow, and a rise of many feet above the highest level ever observed would be required to reach the roadway, which is the lowest part of the rim of the basin. As the heaviest rains do not put the surface appreciably above the maximum level noted, and as that level often remains steady for a long time, the water must pereolate freely away through the soil at higher levels, and the loss of water, when below the maximum must be mainly by evaporation.

The pond has an annual "life" of about 6 months, sometimes 7 months or rather more in wet seasons. It generally begins to fill early in November, and continues through the winter and spring, drying up in May or June. It has an aquatic flora, of which the most prominent members are the Manna Grass (Glyceria) and the moss Fontinalis -, Iris grows at the margin, - but in summer all trace of of these (except the Iris) is hidden under a plentiful growth of terrestrial plants, annual and perennial, Grasses, Docks (Rumex), Ranunculi, and many others which need not be specified.

The observations included the readings of temperatures at the margin, rarely also at the bottom (when the pond was frozen), the collection of plankton, with rough estimates of quantity, the examination of bottom material when available, and notes of the colour of the water. No other physical conditions than temperature were taken into account. It was not convenient to go further, and my simple objects (purely biological) did not require it. No doubt the influence of light was important, but closer observation would have been needed to trace it.

\section{Sketch History of the Season 1906-1907.}

Water first appeared early in November, and on the $12^{\text {th }}$ it was 4 feet in depth. The temperature was then $40^{\circ}, 0 \mathrm{~F}$, and most of the permanent species were present,-nauplii of Diaptomus Castor and small Cyclopids, immature Cyclops and Ostracods, Caddis larvae, Volvox, and Anuraea valga, besides casual species. Daphnia did not come till December.

During December-January the temperature fell steadily, nauplii of D. Castor continued to hatch out in great numbers, and Volvox increased rapidly, The cyclopid young of D. Castor grew progressively larger, but were always succeeded by smaller ones as the nauplii 
changed,- faint indications of sexual differences could be distinguished as early as Dec. $9^{\text {th }}$.

The water was clear, except when stirred up by wind, but as Volvox increased it gave a dull green tinge to it, - it did not, however, render it turbid till April, and the bottom could be seen at 3 or 4 feet.

The surface froze all over twice in December $\left(10^{\text {th }}-15^{\text {th }}\right.$ and $\left.26^{\text {th }}-31^{\text {st }}\right)$, twice in January $\left(3^{\text {rit }}\right.$ and $28^{\text {th }}$ ), and for the last time early in February. Only on January $3^{\text {rd }}$ and February $10^{\text {th }}$ was the ice strong enough to allow of observations in the centre of the pond.

In January, females of D. Castor were found with spermatophores attached, and in February a few of the earliest carried eggs. No nauplii were seen after January.

In March a decided rise of temperature set in and the smaller life of the pond increased conspicuously, - Volvox and A. valga especially began to render the water turbid. 'The collections in the net wert bright green.

The increase continued through April and Volvox filled the nets with a slimy mass after a few casts. The water was quite opaque. and the blending of the red of A. valga with the green of Volvox produced a sort of yellowish green colour.

There was now a culmination of all forms of life in the pond, Volvox made a "Wasserblüte", - A. valga was nearly as plentiful, Daphnia and Chydorus produced males and ephippia, and the eggproduction of D. Castor was at its height.

In May there was some falling off in the quantity of most species except Volvox and Daphnia. The pond nearly dried, but some rain brought it up again in June. Volvox diminished greatly, but A. valga held its ground. Daphnia remained abundant, and produced pseudova for the first time. Diaptomus almost completely disappeared, only one belated cyclopid and a very few nauplii of the new generation being seen.

Late in June the water dried up and the land vegetation took possession.

\section{Temperature.}

The temperature was taken at the margin, always at the same spot, at the foot of the cliff where the talus sloped quickly down to the deepest water. Sometimes readings were taken at other parts in order to observe the effect of wind on the distribution of temperature, 
but the pond was so small that it very quickly became uniform throughout.

Readings were taken when possible 3 times per day, - at 8 a. m., noon, and 4 p. m., - but as the work was done in the intervals of other occupations which often interrupted the noon and evening observations, only the morning readings were used in arriving at the means. This has the disadvantage that it makes the mean of the water temperature appear to stand unnaturally (in such a small pond) higher than the air temperature for a whole month at a time, because the air is (on the average) coolest in the morning, whereas the water is steadier.

Such a very small pond must be liable to rapid changes of temperature during rain, snow, or wind, although the records show no striking examples of such changes. The minor changes of all sorts were doubtless often lost through absence.

Observations were made intermittently over a period of years, but the season 1906-1907 is selected for the accompanying curve, because there were fewer interruptions that year. From the beginning of the series, and throughout the winter, the means are pretty accurate, but from April onward the number of observations was perforce reduced, and at the end of the season they were very few, so that the means for May and June may be considerably out. My experience of other waters leads me to think that for these months they are too high. This need not vitiate the general conclusions, as there is no doubt of the correctness of the trend of the temperature curve, - first, steadily down to the minimum in January-February, - then steadily up to the maximum in May-June.

The Fahrenheit scale was used.

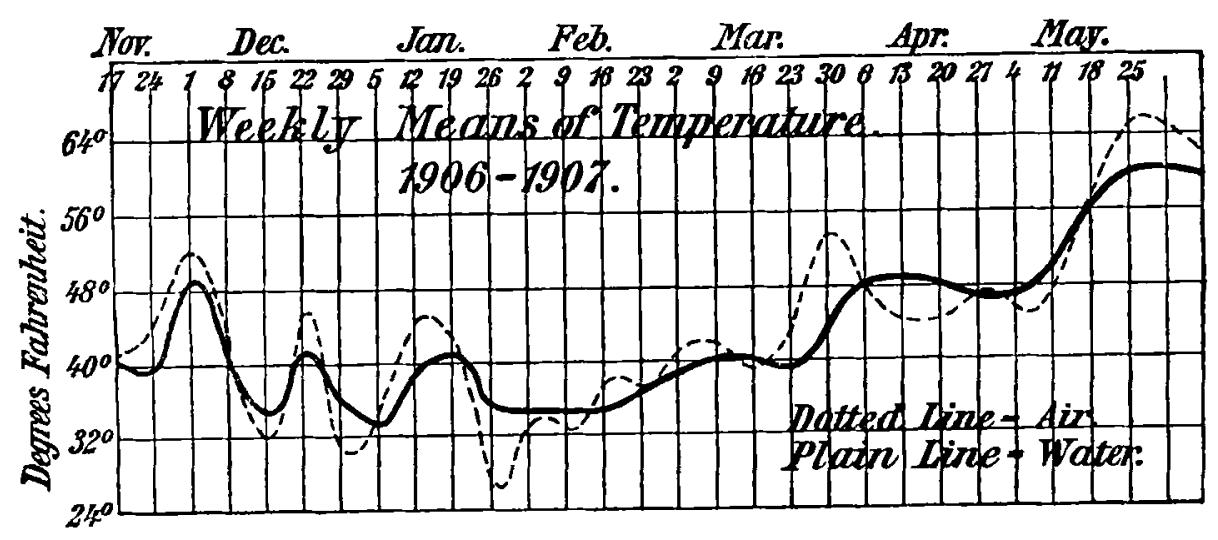


Range of temperature. - The whole variation of the water temperature is about $29^{\circ}$, from just about freezing point to $61,3^{\circ}$; the weekly mean varies between $33,2^{\circ}$ and $60,0^{\circ}$, - the air varies $51^{\circ}$ from $16,0^{\circ}$ in January to $67^{\circ}$ in May and June. The greatest variation of the water in one week is $13,5^{\circ}$ in November, the greatest in one month is scarcely more $\left(14,8^{\circ}\right.$ in December). In the coldest months, January, February and March, the weekly variation is very slight. The greatest, daily variation noted (on many days only one reading could be taken) is no more than $3,5^{\circ}$ (on the same calender day), - greater changes, up to $5^{\circ}$ or $6^{\circ}$, occur between night and morning.

The curves of weekly means, both of air and water, from November to January, show what may be called seiches' of a period of 3 weeks. This is no doubt casual, but the air curve continues to show a somewhat regular oscillation throughout the season.

It is noticeable that the warm weather in May raised the temperature to over $61^{\circ}$, which is not far short of the highest attained in shallow ponds which last through the whole summer, in these same latitudes. This is less surprising when we note that ponds in $77^{\circ}, 30^{\prime}$ south latitude, in a climate where the air just reaches above freezing point for no more than part of each day at midsummer, became almost as warm.

On January $3^{\text {rd }}$, the surface being covered by ice 6 inches thick, the temperature under the ice at the margin was $32,5^{\circ}$; in the centre of the pond it was $5^{0}$ higher, both at surface and bottom.

\section{Biology.}

The biological collections were chiefly made with the planktonnets in the open water. The bottom material could only be examined at the beginning and end of the season, when the water was low: When the level was high there was nothing but grass near the margin, and it was impossible to drag a net over the bottom as a dredge, because it was encumbered by barbed wire, tin cans, and kindred rubbish.

The list of species is very incomplete, - animals of many groups were not identified. While everything which could be recognized has been noted, attention was directed primarily to the Crustacea and Rotifera. The Crustacea were identified for me by Mr. D. G. Scourfield. All the permanent species appeared soon after there was water in the pond, and developed or increased considerably during the coldest 
part of the winter, when the temperature was just above freezing point. This fact indicates that the lowest temperature possible in fresh-water is sufficient for active life and development. An experiment was made in support of this. Some Chydorus were taken from the pond and put in a small bottle to freeze. As long as any water remained liquid, though only as a small vesicle enclosed in ice, the Chydorus went actively about.

When these animals are killed by frost, I believe it is not the temperature which kills them, but the mechanical interference with their functions by the solidifying. In this connection it is interesting to note that in antaretic ponds animals of several classes are frozen for long periods without being killed, and resume activity as soon as there is water to move in. And, in antarctic seas, Invertebrata of various sorts, and even Vertebrata (fish), live and move actively, and reproduce, in water which is always below the freezing point of fresh water, and which is most of the time just appreciably above the freezing point of sea water.

Plankton, - Collections for purposes of comparison were made regularly onco a week, but as occasion offered many additional hauls were made for qualitative exarnination. In such a small pond there can be no sharp distinction between plankton and bottom fauna. Everything which was not rooted was apt to corne into the plankton net. After a continuance of calm weather, however, the two sorts separated themselves, and the nets only caught those organisms with some title to be called plankton species. These were D. Castor, Daphnia pulex. Anuraea valga, and Volvox, with generally some casual species.

These 4 species predominated over all others in the pond every season. No others ever approached them in abundance except sometimes the Ostracods, and on onis occasion the tadpoles of the common frog. They were the characteristic inhabitants of the pond and the only ones which were ever noticed to appreciably affect the colour of the water.

The increasing quantity of all of them as the season advanced has been already noted, but it must be supposed that they increased in different manners. The Volvox and Anuraea actually increased in numbers by reproduction, but with the Daphnia and Diaptomus it was otherwise. As no nauplii of D. Castor were seen after January, and as no ova of Daphnia wore produced till the end of the season 
there could be no reproduction going on, so that, although they bulked more largely in the nets as the season advanced, it must haeve been because of their increase in size, without any increase in numbers, and, allowing for normal mortality from enemies, disease, or accident, there must even have been some decrease.

Quantity, - In ordor to make it possible to roughly estimate the quantity of plankton and of the different species, the collections were always made at the same spot, an in the same manner. It was the same place where the temperature was taken, on the steepest part of the talus under the cliff, and therefore as near as I could get to the deepest water. Two nets of the same size were used, a coarse and a fine, a 'rotifer' net and an 'entomostracan' net. Each was cast 20 times, so as to strain just its fill of water each time.

No attempt was made at accurate quantitive measurement by modern methods. Such measurements have their value, undoubtedly, but from some tests made in Scottish lochs I have come to think that their value is seriously discounted by variations due to unknown or immeasurable factors. In Nerston Quarry there were great and sudden fluctuations in the quantities collected in the same spot in the same manner. These variations I attribute to temporary migrations under the influence of light, temperature, or some other factor. A large animal of slow growth, such as Daphnia pulex, for instance, would be altogether absent from some collections, but would reappear in a day or two as large as ever. For these reasons quantities are indicated throughout this study in common terms such as scarce, abundant etc., and special swarming is specially recorded.

\section{Permanent Fauna and Flora.}

Diaptomus castor (Jurine).

Cyclops bicuspidatus Claus.

C. vernalis Fischer.

Daphnia pulex (De Geor).

Cypris virens (Jurine).

C. fuscata (Jurine).

Chydorus sphaericus (Müller).

Synchaeta pectinata Ehr.

Anuraea aculeata(valga) Ehr.
Notholca striata Ehr.

Volvox globator Ehr.

Glyceria fluitans Br.

Iris pseudacorus L.

Fontinalis antipyretica $L$.

Hypnum stellatum Schreb.

H. cuspidatum L.

Amblystegium filicinum De Not.

Caddis larvae, Collembola, Canthocamptus, Mites, Infusoria, Algae, etc. etc., not identified). 


\section{Casual Species.}

Rana temporaria $L$.

Philodina citrina Ehr.

P. flaviceps Bryce.

Callidina plicata Bryce.

C. natans Murray.

Rotifer vulgaris Schrank.

R. tardigradus Ehr.

Habrotrocha pusilla (Bryce).

H. tridens (Milne).

Synchaeta oblonga Ehr.

Notommata aurita Ehr.

Diurella brachyura (Gosse).
Pterodina reflexa Gosse.

P. mucronata Gosse.

Salpina mutica Perty.

S. mucronata Ehr.

Brachiouus pala Ehr.

B. urceolaris Ehr.

Anuraea aculeata (serrulata) Ehr.

A. cochlearis (tecta) Gosse.

A. cochlearis Gosse.

Notholca scapha Gosse.

Closterium moniliforme (Bory).

C. ncerosum (Gchrank).

\section{Life-Cycles.}

All the organisms noted did not lend themselves equally to the study of the life-cycles. The rotifera as a rule run their life cycle so quickly that stages escaped us in a periodical examination, and closer work is needed for them. The Ostracoda were so often absent from the collections that a continuous record could not be made. The species of Cyclops could not be distinguished when young.

Diaptomus castor. November: nauplii appeared in the damp moss, before even there was any visible water in the pond. December: nauplii continued to appear, along with young in the cyclopid stage up to $300 \mu$ in length,- one very immature male. January: nauplii and young up to $1,8 \mathrm{~mm}$ in length, - female with spermatophores attached. February: Large males and females, a few with eggs. March: females with eggsacs plentiful, -2 nauplii seen. April: males, and females with eggs, plentiful. May: scarce, some females with eggs. June: some years none, sometimes nauplii or large young.

Cyclops 2 sp. mature females with eggs were seen immediately after the pond filled in November. In December there were few with eggs, in January only nauplii and young Cyclopids, in February young and nauplii, in March mature females with eggs again, in May and June only nauplii and very young cyclopids.

Daphnia pulex. Throughout the season Daphnia was very uncertain in its occurence, but this may be attributed to local migrations. It was never noted before December, and was then fairly large, in January large and small occured, in February and March they became progressively larger and at last very abundant, in A pril males 
were seen for the first time, and a fow ephippia, in May there were some males but no ora or ephippia, in June the species was extremely abundant, pseudova were seen for the first time, and ephippia were numerous.

Chydorus sphaericus. First appeared in December, became abundant in March, when pseudova were first seen; in April ephippia were plentiful, and in May there were numerous males.

Synchaeta pectinata. Appeared in December, continued throughout the season; became plentiful in March; eggs seen in April.

Anuraea aculeata, forma valga. Seen as soon as there was water in the pond; eggs in December and every month till June, but there were frequent periods when none were seen carrying eggs. In January and again in April the spines became more nearly equal, sometimes approaching very near to the type.

\section{Sporadic Species.}

Most of the organisms recorded for Nerston Quarry are only casually present. They came for a longer or shorter time in one season, and might never reappear. Only one a two call for any comment.

The Frog (Rana temporaria), was only an occasional visitor. In the spring of 1904 a prodigious quantity of spawn was deposited. The fate of this spawn gainsays a popular belief in the country that the frog has an instinctive knowledge of water which will not dry till the young frogs are ready te leave it. In May the pond was very low, but while there was still an area of many yards square of water surface the tadpoles were so abundant that there was no space between them, - they simply slid over one another. Then tho water departed completely, and for some weeks, till the grass hid it, there was a rich velvety purple deposit of tadpole mud.

Callidina natans Murray. This is one of those extraordinary cases, common enough in nature, of an organism appearing suddenly for a short time, then disappearing utterly. C. natans thus appeared on 24 Nov. 1905. Standing collecting at the accustomed place, the water undisturbed and clear, I got a quantity of this swimming Bdelloid, evidently built for swimming, since it didnt seem to know the ordinary use of its toes. Next day I sought for it in the same spot, but it was gone, and that remains the sole record of its presence on earth. 
Pterodina mucronata Gosse was found in great abundance among the Fontinalis on one occasion when the water was very low. A few days later none could be found among moss from the same spot.

\section{Sumrnary.}

Reviewing the work done, in view of the objects with which it was undertaken, we find the following results.

First. - Diaptomus castor, Daphnia pulex, Chydorus sphaericus, and Synchaeta pectinata seem only to produce eggs once, late in the season, in this pond. They have only one generation per season. Cyclops (2 species) reaches maturity very early, and there is more than one generation. Anuraea valga passes through many generations.

Second. - All the predominant species appeared almost as soon as there was any water, and doveloped or reproduced in the coldest months, with the temperature just above freezing point. No striking increase in quantity occurred till the temperature began to rise, and the increase reached its maximum with the highest temperatures. It is believed that those invertebrata which are killed by freezing are not killed by the low temperature, but by the mechanical effects of the freezing.

Third.-Examination of the pond, year by year, from 1902 to 1907, showed that all the abundant organisms, about 10 species, were constant in their occurrence. The number of constant species is probably really much greater, if they were better known.

Fourth. - The comparison of periodic and permanent ponds has not even been begun, but is seems likely that the periodical examination of isolated ponds of various characters, even if conducted on no more ambitious lines than those followed in this instance, would yield results of some interest, and, compared one with another, might throw light on various biological probloms, especially on the adaptability of species to varied conditions, and on questions of distribution.

It would be easy, according to opportunity and the equipment of the investigator, to extend the scope of the inquiry, and to include such items as chemical analysis of the water, the geological nature of the basin, the accurate measurement of quantity, the study of seasonal variation, besides taking a wider field biologically, including groups 
which I had to neglect, and aiming at more complete studies of lifehistories.

A complete history of periodic pond would require the demonstration of the presence of the resting eggs in the dry season. It was intended to seek them in Nerston Quarry, but summer always took me far away from the locality. Experiments should be made in cutting short their resting period, to observe their behaviour. Much remains to be done.

Gegenstand der Untersuchung ist ein Teich ohne Zu- und AbfluB, welchor während des Winters (November bis Mai-Juni) Wasser enthālt, während des Sommers dagegen austrocknet.

Gleichwohl fand sich eine permanente Fauna und Flora (1902-1907 beobachtet), neben sporadischen Finwanderern. -

Die permanenten Bewohner treten sogleich nach dem ersten Eintritt von Wasser, also zu Beginn des Winters auf; sie entwickeln sich während der kältesten Jahreszeit. -

Diaptomus castor, Daplnia pulex, Chydorus sphaericus, Synchaeta pectinata scheinen nur einmal und zwar gegen Ende der Periode (im Frühjabr) Eier zu produzieren. Cvclops (biscuspidatus und vernalis) dagegen pflanzen sich schon im Winter fort (polyzyklisch), ebenso Anuraea aculeata. -

Ein Vergleich der Jahreszyklen in periodischen und in permanenten Teichen wird vom Verfasser als besonders aussichtsreich bezeichnet, zumal wenn dabei alle für das Loben eines Gewästers wichtigen (chemischen, geologischen etc.) Faktoron berücksichtigt und die quantitativen Methoden sowie diejenigen der Variationsforschung angewendet werden kônnten. - 